\title{
Sepsis Neonatal di NICU RSAB Harapan Kita Jakarta
}

Setyadewi Lusyati*, Pieter J.J. Sauer ${ }^{* *}$

* Unit Kerja Neonatologi, Bag. Ilmu Kesehatan Anak, Rumah Sakit Anak dan Bunda Harapan Kita, Jakarta

** Department of Pediatrics/Beatrix Children's Hospital, University Medical Center Groningen,The Netherlands

Latar belakang. Angka kejadian infeksi pada neonatus di negara berkembang sangat tinggi, terutama di Unit Pelayanan Intensif Neonatal (NICU). Pemberian antibiotik diharapkan dapat mengeradikasi infeksi neonatal. Namun di lain sisi pemakaian antibiotik spektrum luas dapat memicu munculnya bakteri yang lebih resisten dan berbahaya.

Tujuan. Mengetahui angka kejadian sepsis neonatal, bakteri penyebab sepsis dan penggunaan antibiotik. Metode. Uji retrospektif terhadap bayi yang lahir dan dirawat di NICU RSAB Harapan Kita, Jakarta antara bulan Mei 2003 sampai Juni 2005.

Hasil. Didapatkan 216 bayi dirawat di NICU, 133 diantaranya dicurigai mengalami infeksi, namun hanya 9 biakan darah positif pada hari I. Antibiotik diberikan terhadap 133 bayi. Pada hari ke 3-5, terdapat 63 bayi dengan biakan darah positif pada hari ke 3-5 dari 74 bayi dengan gejala sepsis yang menetap. Semua bayi dengan kecurigaan sepsis mendapat antibiotik antenatal. Bakteri Gram negatif terutama Serratia marcescens menempati urutan pertama baik pada biakan hari ke-1 maupun ke 3-5. Angka kejadian infeksi tidak berhubungan dengan usia gestasi dan antibiotik antenatal.

Kesimpulan. Angka kejadian sepsis neonatal pada hari I di RSAB Harapan Kita sebanding dengan di negara maju. Namun kejadian sepsis pada hari ke 3-5 meningkat tajam, dengan bakteri Gram negatif sebagai penyebab utama. Hal ini menunjukkan tingginya tingkat kejadian infeksi nosokomial. (Sari Pediatri 2007; 9(3):173-177).

Kata kunci: sepsis neonatal, Serratia

Alamat korespondensi

Dr. Setyadewi Lusyati.

Unit Kerja Neonatologi, Bag. Ilmu Kesehatan Anak, Rumah Sakit Anak dan Bunda Harapan Kita, Jakarta .

Telp/fax. 62-21-53152570; e-mail: setyadewi13@yahoo.com.
A

ngka kematian neonatal di negara berkembang sekitar 34 per 1000 kelahiran hidup. Kematian tersebut terutama pada periode perinatal. ${ }^{1}$ Berdasar perkiraan WHO, infeksi, prematuritas dan asfiksia adalah penyebab tersering. ${ }^{2,3}$ Analisis studi dari Pakistan 
menunjukkan bakteri Gram negatif adalah penyebab utama infeksi neonatal di Negara berkembang. ${ }^{4}$ Beberapa penelitian dari Asia dan Australia menunjukkan bahwa bakteri penyebab infeksi neonatal di tiap pusat pelayanan bervariasi dan dipengaruhi beberapa faktor. ${ }^{5,6,7,8,9}$ Salah satu faktor yang diduga berperan penting adalah pemberian antibiotik. Diduga antibiotik baik yang diberikan antenatal maupun pascanatal dapat memicu pertumbuhan bakteri yang sangat virulen. ${ }^{10}$ Penelitian ini merupakan penelitian awal dan bagian dari penelitian prospektif yang akan dilakukan di unit kami. Tujuan penelitian ini adalah mengetahui kejadian infeksi neonatal pada hari ke-1 dan ke 3-5, mencari bakteri penyebab dan pola sensitivitasnya.

\section{Metode}

Penelitian ini merupakan uji observasional yang bersifat retrospektif. Populasi penelitian adalah bayi baru lahir di RSAB Harapan Kita, Jakarta yang memerlukan perawatan NICU, pada periode Mei 2003-Juni 2005. Bayi dimasukkan ke dalam subyek penelitian bila diduga secara klinis mengalami infeksi pada usia hari pertama. Data ibu dan bayi diperoleh melalui catatan medis. Pencatatan data ibu meliputi usia ibu, ketuban pecah dini lebih dari $12 \mathrm{jam}$, suhu di atas $38^{\circ} \mathrm{C}$ dan abnormalitas kardiotokografi (CTG). Pencatatan data bayi meliputi berat lahir, usia kehamilan jenis kelamin dan jenis persalinan. Pemberian antibiotik (ampisilin atau generasi ketiga sefalosporin) pada ibu sebelum persalinan karena kelahiran secara operasi atau ibu mempunyai risiko infeksi juga dicatat. Bayi diduga sepsis bila menunjukkan gejala klinis infeksi seperti gangguan pernafasan, bradikardi, letargi, malas minum, kejang atau suhu tidak stabil. Skrining untuk sepsis dilakukan termasuk biakan darah. Biakan darah menggunakan metoda Bactec. Antibiotik lini pertama $(150 \mathrm{mg} / \mathrm{kg}$ ampisilin-sulbaktam dan $15 \mathrm{mg} / \mathrm{kg}$ amikasin) segera diberikan sebelum dilakukan pengambilan biakan darah. Biakan kedua pada hari ke 3-5 diambil bila dari

Tabel1. Karakteristik ibu dan neonatus yang dirawat

\begin{tabular}{|c|c|c|c|c|c|c|c|}
\hline \multirow[t]{2}{*}{ Variabel } & \multirow{2}{*}{$\begin{array}{c}\text { Subjek } \\
\mathrm{n}=216\end{array}$} & \multicolumn{2}{|c|}{ Curiga infeksi $(\mathrm{n}=133)$} & \multicolumn{2}{|c|}{ Curiga EOS* $(n=9)$} & \multicolumn{2}{|c|}{ Curiga LOS* $(n=63)$} \\
\hline & & No & $\%$ & No & $\%$ & No & $\%$ \\
\hline \multicolumn{8}{|l|}{ Ibu } \\
\hline$<20$ tahun & 27 & 15 & 11,3 & 1 & 11,1 & 7 & 11,1 \\
\hline $\mathrm{KPD}>12$ & 18 & 15 & 11,3 & 0 & 0 & 7 & 11,1 \\
\hline Antibiotik & 163 & 105 & 78,9 & 9 & 100 & 49 & 77,8 \\
\hline Temperatur $\geq 38$ & 15 & 11 & 8,3 & 3 & 33,4 & 6 & 9,5 \\
\hline CTG* abnormal $^{*}$ & 16 & 14 & 10,5 & 3 & 33,4 & 5 & 7,9 \\
\hline \multicolumn{8}{|l|}{ Bayi } \\
\hline \multicolumn{8}{|c|}{ Usia gestasi (minggu) } \\
\hline$<30$ & 32 & 18 & 13.5 & 0 & 0 & 10 & 15.8 \\
\hline $31-34$ & 46 & 36 & 27.1 & 2 & 22.2 & 18 & 28.6 \\
\hline $35-<37$ & 37 & 22 & 16.5 & 1 & 11.1 & 10 & 15.8 \\
\hline$>37$ & 101 & 58 & 43.6 & 6 & 66.6 & 25 & 39.7 \\
\hline \multicolumn{8}{|l|}{ Tipe persalinan } \\
\hline Spontan & 56 & 30 & 22,6 & 1 & 11,1 & 15 & 23,8 \\
\hline Seksio sesaria & 160 & 104 & 77,4 & 8 & 88,9 & 48 & 76,2 \\
\hline \multicolumn{8}{|l|}{ BBL (gram) } \\
\hline$<1000$ & 6 & 1 & 0,8 & 0 & 0 & 1 & 1,6 \\
\hline $1000-<1500$ & 30 & 22 & 16,5 & 1 & 11,1 & 9 & 14,3 \\
\hline $1500-<2500$ & 84 & 47 & 35,3 & 1 & 11,1 & 23 & 36,5 \\
\hline$>2500$ & 96 & 63 & 47,2 & 7 & 77,8 & 28 & 44,4 \\
\hline Apgar 5 min $<3$ & 6 & 2 & 1,5 & 0 & 0 & 0 & 0 \\
\hline \multicolumn{8}{|l|}{ Jenis kelamin } \\
\hline Laki laki & 75 & 63 & 47,4 & 6 & 66,6 & 35 & 55,6 \\
\hline Perempuan & 141 & 70 & 52,6 & 3 & 33,4 & 28 & 45,4 \\
\hline${ }^{*} \mathrm{EOS}=$ early onset sepsi & $S=$ late on & et sepsis & $\Gamma \mathrm{G}=$ kardic & cokogra & & & \\
\hline
\end{tabular}


biakan pertama tidak didapatkan bakteri dan bayi tidak menunjukkan perbaikan secara klinis. Diagnosis sepsis neonatal ditegakkan bila didapatkan bakteri dari biakan darah. Curiga early onset sepsis (EOS) bila didapatkan biakan darah positif pada hari ke1 dan curiga late onset sepsis (LOS) bila didapatkan biakan darah positif pada hari ke 3-5. Pada bayi dengan biakan darah yang positif, pemberian antibiotik dilanjutkan hingga 14 hari.

\section{Statistik}

Uji Pearson chi square digunakan untuk mengevaluasi hubungan antara kejadian sepsis dengan usia kehamilan. Uji Fisher exact digunakan untuk mengevaluasi hubungan antara pemberian antibiotik antenatal dan kejadian sepsis. Kompilasi data menggunakan program SSPS (versi 10.0, SSPS Inc., Chicago).

\section{Hasil}

Selama periode Mei 2003 - Juni 2005, terdapat 6600 bayi lahir di RSAB Harapan Kita, Jakarta. Didapatkan 216 bayi dari 6600 memerlukan perawatan NICU. Dari 216 bayi yang dirawat di NICU, terdapat 163 bayi memperoleh antibiotik sebelum lahir dan 160 bayi dilahirkan secara operasi. Alasan utama pemberian antibiotik adalah kelahiran sesar atau ibu mengalami demam. Tidak didapatkan hubungan antara kejadian infeksi hari ke1 dan ke 3-5 terhadap faktor ibu seperti ketuban pecah dini (KPD) $>12$ jam, suhu ibu dan abnormalitas CTG. Demikian juga terhadap faktor bayi seperti berat badan lahir (BBL), usia kehamilan, skor Apgar, dan tipe persalinan (Tabel 2).

Tabel 2. Kejadian infeksi hari ke 1 dan 3-5 terhadap kelompok usia gestasi

\begin{tabular}{lllllll}
\hline $\begin{array}{l}\text { Usia gestasi } \\
(\text { minggu })\end{array}$ & \multicolumn{2}{c}{ Hari 1} & Nilai $\mathrm{p}$ & \multicolumn{2}{c}{ Hari 3-5 } & Nilai $\mathrm{p}$ \\
\cline { 2 - 3 } & + & - & & + & - & \\
\hline 30 & 0 & 18 & & 10 & 2 & \\
$31-34$ & 2 & 34 & & 18 & 4 & \\
$35-<37$ & 1 & 21 & 0,51 & 10 & 0 & 0,64 \\
$\geq 37$ & 6 & 52 & & 25 & 5 & \\
\hline
\end{tabular}

Diantara 216 bayi, didapatkan 133 bayi dengan kecurigaan infeksi. Data ibu dan bayi yang dicatat seperti pada Tabel 1. Biakan darah diperiksa terhadap 133 bayi dan 9 diantaranya ditemukan bakteri (Tabel 3). Empat dari $9(44,4 \%)$ adalah Serratia sp. Pada biakan darah hari ke 3-5, 63 dari 74 positif bakteri dengan dominasi kuman yang sama $(85,1 \%)$ dan 9 $(12,1 \%)$ ditemukan Klebsiella pneumonia. Pola sensitivitas bakteri menunjukkan resistensi yang tinggi terhadap antibiotik ampisilin dan kecenderungan resistensi terhadap ampisilin sulbaktam meningkat pada hari ke 3-5 dibanding hari I (Tabel 4).

\section{Diskusi}

Infeksi pada periode neonatus dibedakan menjadi 2 berdasarkan awitan kejadian infeksi. Infeksi dini (EOS) adalah infeksi yang terjadi pada usia 72 jam pertama dan infeksi lanjut terjadi selanjutnya (>usia 72 jam). ${ }^{11}$ Penyebab infeksi pada 2 kejadian tersebut adalah

Tabel 3. Hasil biakan darah hari ke 1 dan 3-5

\begin{tabular}{lcc}
\hline & \multicolumn{2}{c}{ Kultur darah } \\
\cline { 2 - 3 } & $\begin{array}{c}\text { Hari ke 1 } \\
(\mathrm{n}=133)\end{array}$ & $\begin{array}{c}\text { Hari ke 3-5 } \\
(\mathrm{n}=74)\end{array}$ \\
\hline Steril & 125 & 11 \\
$\begin{array}{l}\text { Bakteri patogen: } \\
\quad \text { Serratia sp }\end{array}$ & 4 & 45 \\
Strep. haemolyticus & 1 & - \\
Klebsiella pnemoniae & 1 & 9 \\
E. aerogenes & 1 & 7 \\
Staph. aureus & 2 & - \\
Pseudomonas & - & 1 \\
Strep.pyogenes & - & 1 \\
\hline
\end{tabular}

Tabel 4. Pola sensitivitas bakteri hari ke 1 dan 3-5

\begin{tabular}{lcccc}
\hline & \multicolumn{3}{c}{ Hari ke $1(\mathrm{n}=9)$} & Hari ke $3-5(\mathrm{n}=63)$ \\
\cline { 2 - 5 } Antibiotik & No. & $\%$ & No. & $\%$ \\
\hline Ampisilin & 3 & 37,5 & 21 & 33,3 \\
Ampisilin-sulbaktam & 7 & 77,8 & 36 & 58,1 \\
Gentamisin & 5 & 62,5 & 55 & 74,3 \\
Amikasin & 5 & 62,5 & 52 & 85,2 \\
Cefotaksim & 6 & 75,0 & 43 & 69,4 \\
Ceftazidim & 4 & 50,0 & 43 & 69,4 \\
Meropenem & 7 & 87,5 & 57 & 91,9 \\
\hline
\end{tabular}


berbeda. Infeksi dini terutama disebabkan pada periode perinatal. Bakteri penyebab tersering adalah bakteri dari flora normal saluran cerna dan jalan lahir ibu, seperti group B streptococci, Hemophilus influenzae, E. coli dan Listeria monositogenes. Empat kuman tersebut adalah kuman penyebab utama di negara maju yang ditemukan sebelum era antibiotik profilaksis perinatal diberikan. ${ }^{10,11,12,13}$ Pada infeksi lanjut (LOS) lebih disebabkan karena nosokomial akibat sarana dan peralatan modern di neonatal intensive care units (NICU), seperti group stafilokokus (terutama 'coagulase-negative Staphylococci') dan Candida sp. ${ }^{11,12,13}$ Stoll BJ dkk ${ }^{10}$ melalui analisis penelitian yang dilakukan di beberapa Negara di US, menemukan kejadian infeksi dini berkisar 15-19/1000 kelahiran hidup pada bayi dengan kisaran BB 401-1500 gram. Seiring dengan aplikasi antibiotik profilaksis terhadap Streptococcus group B, kejadian infeksi akibat bakteri tersebut menurun secara dramatis, namun kejadian infeksi dini akibat $E$ coli stabil dan cenderung meningkat dengan insidensi 6.8 kasus/1000 kelahiran disertai gejala klinis yang berat dengan tingkat mortalitas yang tinggi. Angka kejadian infeksi dini di NICU- University Medical Center Groningen/Beatrix Children's Hospital sekitar 0,5/1000 kelahiran. ${ }^{14}$

Pada penelitian ini terdapat dua hal kejadian sepsis yang menarik. Sesuai dengan baku emas bahwa sepsis neonatal ditegakkan bila ditemukan bakteri dari biakan darah. Kami mendapatkan 9 sepsis terjadi pada usia hari I, dan 63 sepsis terjadi pada usia hari ke 3-5. Dari 63 bayi tersebut, 9 diantaranya juga mengalami sepsis pada usia hari I. Dengan demikian angka kejadian infeksi di NICU RSAB Harapan Kita adalah 9/6600 kelahiran atau 1,4/1000 kelahiran. Angka ini bila dibandingkan dengan negara maju sebanding. Namun bila kita bandingkan terhadap usia gestasi, maka angka tersebut akan menjadi sedikit lebih tinggi. Di unit kami, terdapat $13.5 \%$ bayi dengan usia gestasi $<30$ minggu dan $<1 \%$ dengan BBL $<1000$ gram. Sudah diketahui secara pasti bahwa kejadian infeksi akan meningkat sesuai dengan menurunnya usia gestasi dan berat badan lahir.

Perbedaan yang lain dengan negara maju seperti Eropa dan Amerika adalah dalam hal bakteri penyebab sepsis. ${ }^{10,13,14,15}$ Di unit kami Serratia marcescens adalah bakteri penyebab utama. Melihat dominasi kuman tersebut pada 2 kejadian infeksi, maka belum jelas apakah kejadian infeksi dini di unit kami disebabkan karena transmisi bakteri secara perinatal dari ibu atau terkontaminasi setelah lahir baik akibat proses persalinan atau hari pertama saat dirawat. Pengaruh antibiotik antenatal terhadap munculnya Serratia sp dengan kecenderungan resisten terhadap ampisilin belum jelas (Tabel 5). Bila menyimak penelitian yang dilakukan di Amerika Serikat mengenai munculnya E. coli dengan tingkat resistensi terhadap ampisilin yang tinggi seiring dengan pemberian antibiotik ampisilin perinatal, maka Serratia sp dengan resisten terhadap ampisilin di unit kami mungkin dapat dipengaruhi oleh pemberian antibiotik antenatal tersebut. Namun hal ini memerlukan evaluasi lebih lanjut.

Kejadian infeksi yang tinggi ditemukan pada hari ke 3-5 di unit kami bahkan pada bayi dengan antibiotik sebelumnya. Sebagian besar kejadian infeksi tersebut disebabkan oleh Serratia marcescens kemudian diikuti Klebsiella pneumoniae. Dengan mempertimbangkan penemuan dua jenis kuman tersebut, maka dipastikan kuman penyebab sepsis adalah nosokomial. Yang menarik adalah kejadian tersebut tidak berbeda terhadap perbedaan kelompok usia gestasi (Tabel 4). Penemuan ini mengindikasikan bahwa sumber kuman penyebab tersebut mungkin berhubungan dengan tindakan yang secara umum dilakukan terhadap bayi bayi yang dirawat di NICU. Penemuan ini mengindikasikan adanya masalah infeksi nosokomial yang sangat serius dan memerlukan upaya segera secara menyeluruh dan terkait untuk menurunkannya.

Rendahnya kejadian infeksi dini di unit kami pada hari I mungkin dipengaruhi pemberian antibiotika antenatal. Namun ini masih sebatas pendapat yang

Tabel 5. Kejadian infeksi hari ke 1 dan 3-5 terhadap antibiotika antenatal

\begin{tabular}{ccccccc}
\hline & \multicolumn{2}{c}{ Hari $1(\mathrm{n}=133)$} & & & Hari 3-5 $(\mathrm{n}=74)$ & \\
\cline { 2 - 3 } Antibiotik antenatal & $\begin{array}{c}\text { Positif } \\
(\mathrm{n}=9)\end{array}$ & $\begin{array}{c}\text { Negatif } \\
(\mathrm{n}=124)\end{array}$ & Nilai $\mathrm{p}$ & $\begin{array}{c}\text { Positif } \\
(\mathrm{n}=63)\end{array}$ & $\begin{array}{c}\text { Negatif } \\
(\mathrm{n}=11)\end{array}$ & nilai $\mathrm{p}$ \\
\hline Ya & 7 & 98 & & 49 & 9 & \\
tidak & 2 & 16 & 0,20 & 14 & 2 & 0,44 \\
\hline
\end{tabular}


perlu dibuktikan kebenarannya. Bagaimanapun juga, terdapat penelitian yang menyatakan bahwa pengambilan darah sebanyak $0,5 \mathrm{cc}$ pada satu sisi daerah pengambilan dan pemeriksaan kultur dengan menggunakan metoda Bactec adalah akurat. ${ }^{17}$ Terlebih lagi seluruh bayi yang dilakukan ulangan biakan darah mendapat antibiotik dan tetap menunjukkan hasil yang positif. Kita tidak dapat menyimpulkan bahwa tidak terdeteksi bakteri dari biakan darah hari I adalah akibat dari pemberian antibiotik antenatal. Dengan demikian, upaya diagnosis infeksi secara dini dengan menggunakan metoda lain diperlukan.

Sebagai kesimpulan, kejadian infeksi dini di unit kami, NICU-RSAB Harapan Kita Jakarta adalah rendah dan sebanding dengan kejadian di negara maju. Tingginya angka kejadian sepsis hari ke 3-5 merupakan infeksi nosokomial yang memerlukan upaya segera untuk menurunkan kejadiannya.

\section{Ucapan Terima Kasih}

Kami ucapkan terima kasih kepada Hadyana Sukandar atas bantuan dalam membuat tabulasi data dan analisa statistik.

Penelitian ini mendapat dukungan dana dari Nestle Nutrition Institute-Pediatric Scholarship Award "in Neonatology studies", Switzerland, 2005. Dipresentasikan di Kongres "Society for Pediatric Research", San Fransisco, May 2006.

\section{Daftar Pustaka}

1. Costello A, Francis V, Byrne A. The states of the world's newborns. Washington: Save the Children Fund, 2001.

2. WHO. Perinatal Mortality. Report No.:WHO/FRH/ MSM/967. Geneva: WHO, 1996.

3. Stoll BJ. The global impact of neonatal infection. Clin Perinatol 1997; 24:1-21.

4. Zaidi A, Huskin WC, Thaver D. Hospital acquired neonatal infections in developing countries, Lancet 2005; 365:1175-88.
5. Nathoo KJ, Mason PR, Chimbira TH. Neonatal septicaemia in Harare hospital: aetiology and risk factors. Centr Afr J Med 1990; 36:150-6.

6. Boo Ny, Chor CY. Six years trend of Neonatal septicaemia in a large Malaysian maternity hospital. J Paediatr Child Health 1994; 30:23-7.

7. Bhutta ZA, Yusuf K. Early onset neonatal sepsis in Pakistan: a case control study of risk factors in a birth cohort. Am J Perinatol 1997; 14:577-81.

8. Kuruvilla KA, Pillai S, Jesudason M, Jana AK. Bacterial profile of sepsis in a neonatal unit in a South India. Indian Pediatr 1998; 35:851-8.

9. Pessoa-Silva CR, Ricthman R, Calil R. Health care associated infection among neonates in Brazil. Infect Control Hosp Epidemiol 2004; 25:772-7.

10. Stoll BJ, Hansen N. Infection in VLBW Infants: Studies from the NICHD Neonatal Research Network. Seminars in Perinatology 2003; 27:293-301.

11. Tiffany SG, Paul CY, Jordan W. Association of intrapartum antibiotic exposure and late onset serious bacterial infection in infants. Pediatrics 2005; 116:696-702.

12. Musoke RN, Revathi G. Emergence of multidrug-resistant gram-negative organisms in a neonatal unit and the therapeutic implications, J Trop Pediatr 2000; 46: 86-91.

13. Staphanie JS, Stoll B. Early onset neonatal sepsis in the era of widespread intrapartum chemoprophylaxis. Pediatr Infect Dis J 2006; 25:939-40.

14. Lusyati, Paul vd Berg, PJJ Sauer. Late onset sepsis in Groningen (in press). Presented at Society for Pediatric Research Congress, San Fransisco, May, 2006.

15. Aurangzeb B, Hameed A. Neonatal sepsis in hospitalborn babies: bacterial isolates and antibiotic susceptibility patterns. J Coll Physicians Surg Pak 2003; 13:62932.

16. Stoll BJ, Hansen N, Fanaroff AA. Late onset sepsis in very low birth weight neonatus: the experience of the NICHD Neonatal Research Network. Pediatrics 2002; 110:285-91.

17. Sarkar S, Bhagat JD, Wiswell TE, Spitzer AR. A study of the role of multiple site blood cultures in the evaluation of neonatal sepsis. J of Perinatology 2005:1-5. 